
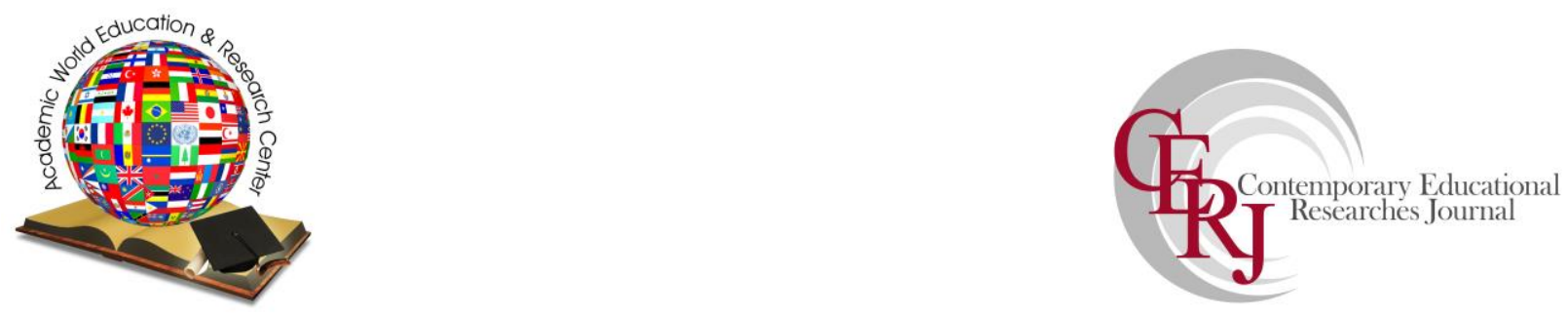

\title{
Challenging paradigms in the continuous training of teachers from curricular area Mathematics and Science
}

Abstract sciences (Proweb)

1. The merging paradigms: Training and continuous training

septem artes liberals 
Sorin-Avram Virtop, Challengings paradigms in the continuous training of teachers from the curricular area Mathematics and Science / Contemporary Educational Researches Journal (2012) 000-000

ex cathedra 
1. The Curricular reform since $\mathbf{1 9 8 9}$ and the training of teachers: towards teaching as a profession 
2. Continuous training of teachers from curricular area Mathematics and Science

"Network of training teachers to use multimedia, virtual instrumentation and web 2.0 in the curriculum area of Mathematics and Natural Sciences (ProWeb) 
Sorin-Avram Virtop, Challengings paradigms in the continuous training of teachers from the curricular area Mathematics and Science / Contemporary Educational Researches Journal (2012) 000-000 
Pedagogical Fundamentals for using the technology of information and computers in continuous training of teachers from the curricular area of Mathematics and Natural sciences 
Virtual Instrumentation and educational software

\section{What teachers do for the future}




\section{Acknowledgements}

\section{References}

). A taxonomy for Learning, Teaching, and Assessing: A revision of Bloom's Taxonomy of Educational Objectives

Evaluarea continuă a elevilor şi examenele, manualul de docimologie

school at the beginning of the IIIrd milenium)

\section{Websites}

